\title{
Karakteristik Batu Bata Campuran Hasil Sedimentasi Penambangan Batu Gamping Area 412,3 Ha Bukit Tajarang
}

\author{
Totoh Andayono ${ }^{1 *}$, Eka Juliafad ${ }^{2}$, Rusydi Halim ${ }^{3}$ \\ ${ }^{1,2}$ Jurusan Teknik Sipil, Fakultas Teknik, Universitas Universitas Negeri Padang \\ ${ }^{3}$ Jurusan Teknik Sipil, FTSP, ITP \\ *Corresponding author, e-mail: to.handayono@gmail.com
}

\begin{abstract}
Abstrak-Rumah dengan kategori non-engineering houses saat terjadinya gempa banyak mengalami kerusakan, hal ini disebabkan dinding rumah dengan bahan batu bata yang tidak memenuhi persyaratan mutu yang ada. Pemerintah telah mengupayakan dengan menetapkan petunjuk teknis untuk rumah aman gempa (key requirement for safer houses), namun demikian batu bata yang telah dan sedang digunakan masyarakat sampai saat ini masih belum dapat dijamin kualitasnya. Solusi untuk meningkatkan mutu yang dihasilkan, salah satunya dengan membuat batu bata yang bermutu dan aman terhadap gempa dengan bahan baku campuran hasil sedimentasi dari erosi daerah penambangan batu gamping (limestone). Pemanfaatan hasil sedimentasi ini sekaligus sebagai upaya mengurangi dampak laju sedimentasi pada sungai Batang Arau kota Padang. Pembuatan batu bata dengan proporsi campuran tanah hasil sedimentasi $50 \%, 45 \%, 40 \%, 35 \%, 30 \%, 25 \%, 20 \%, 15 \%, 10 \%, 5 \%$, selanjutnya pengujian mutu batu bata mengacu SNI 15-2094-2000. Hasil pengujian diperoleh, penyerapan air batu bata campuran bahan sedimentasi $14,16 \%(<20 \%$ :memenuhi standart SNI), kuat tekan rata-rata batu bata campuran bahan sedimentasi sebesar $32,56 \mathrm{~kg} / \mathrm{cm}^{2}\left(\geq 30 \mathrm{~kg} / \mathrm{cm}^{2}:\right.$ memenuhi persyaratan kuat tekan minimum membangun rumah aman gempa) serta didapatkan komposisi tanah lempung $\mathbf{7 0 \%}$ dan bahan sedimentasi $30 \%$ memberikan mutu bata tertinggi.
\end{abstract}

Kata Kunci : hasil sedimentasi, batu gamping, batu bata

\begin{abstract}
Houses with the category of non-engineering houses during the earthquake experienced a lot of damage, this is due to the walls of the house with brick materials that do not meet the existing quality requirements. The government has sought to establish key requirements for safer houses, however, the quality of the bricks that have been and are being used by the community until now is still not guaranteed. The solution to improve the quality produced, one of which is by making earthquake-safe and quality bricks with mixed raw materials resulting from sedimentation from erosion of limestone mining areas. The utilization of these sedimentation results is also an effort to reduce the impact of the sedimentation rate on the Batang Arau river in Padang. The making of bricks with the proportion of soil mixtures resulting from sedimentation is $50 \%, 45 \%, 40 \%, 35 \%, 30 \%, 25 \%, 20 \%, 15 \%, 10 \%, 5 \%$, then the quality testing of bricks refers to SNI 15-2094- 2000. The results were obtained, the absorption of brick water mixed with sedimentation material $14.16 \%(<20 \%$ : fulfilling SNI standards), the average compressive strength of the mixture of sedimentation materials was $32.56 \mathrm{~kg} / \mathrm{cm}^{2}\left(\geq 30 \mathrm{~kg} / \mathrm{cm}^{2}\right.$ : meeting the requirements the minimum compressive strength of building an earthquake-safe house) and obtained a composition of $70 \%$ clay and $30 \%$ sedimentation material providing the highest brick quality.
\end{abstract}

Keywords : sedimentation results, limestone, brick

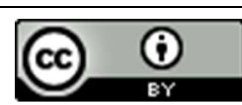

This is an open access article distributed under the Creative Commons 4.0 Attribution License.

\section{I.PENDAhUluan}

Peta sebaran kerusakan rumah akibat gempa Sumatera Barat 2009 (7,6 SR) dari Pusdalops
BNPB menunjukkan kerusakan rumah dengan kategori rusak sedang sampai berat adalah di daerah dengan indeks kerawanan bencananya 
tinggi seperti Pesisir Selatan, Padang, Padang Pariaman dan Pasaman Barat. Sebanyak 3240 (Pasaman Barat), 11.173 (Agam), 6.685 (Pariaman), 57.771 (Padang Pariaman), 37.587 (Padang) Pesisir Selatan sebanyak 2.187, dengan kategori sebagai non-engineering houses atau rumah sederhana tembokan dengan dinding menggunakan bahan batu bata merah [1]. Kerusakan ini disebabkan karena penggunaan bahan bangunan untuk dinding (batu bata) yang tidak memenuhi persyaratan mutu yang ada.

Hasil penelitian tim Universitas Negeri Padang bersama JICA [2], diketahui kualitas batu bata yang digunakan masyarakat dan dihasilkan oleh pabrik batu bata lokal di wilayah Kabupaten Padang Pariaman masih belum memenuhi syarat kekuatan yang ditentukan. Kalaupun ada, hanya memenuhi syarat minimum yaitu $25 \mathrm{~kg} / \mathrm{cm}^{2}$. Hal ini didukung hasil penilitian [3], menyatakan kualitas batu bata yang digunakan masyarakat saat rekonstruksi rumah pascagempa dan hasil pabrik di daerah gempa (Kabupaten Padang Pariaman) tidak memenuhi persyaratan yang berlaku (bentuk fisik, ukuran batu bata dan kuat tekan), memiliki berat rata-rata 2,3 -2,5 $\mathrm{kg}$ per buah dan kuat tekan rata-rata minimum 15,25 $\mathrm{kg} / \mathrm{cm}^{2}$.

Pemerintah telah mengupayakan usaha mitigasi bencana bumi dengan menetapkan petunjuk teknis untuk rumah aman gempa (Key Requirement for safer houses), dengan harapan dapat menjadi pedoman bagi masyarakat demi terciptanya bangunan yang lebih aman terhadap gempa. Sebagai petunjuk teknis yang didasarkan pada teori, maka material yans digunakan pada konstruksi rumah sederhana diasumsikan sudah memenuhi persyaratan, baik mutu beton, tulangan, maupun batu bata. Dalam hal ini, masalah yang muncul adalah mutu batu bata yang telah dan yang sedang digunakan masyarakat khususnya di daerah Sumatera Barat masih belum dapat dijamin kualitasnya baik dari segi kekuatan, keseragaman ukuran, porositas dan sifat mekanik lainnya.

Dalam meningkatkan mutu batu bata adalah dengan inovasi menciptakan batu bata yang bermutu dan lebih aman terhadap gempa. Salah satunya dengan memanfaatkan bahan hasil sedimentasi penambangan batu gamping (limestone) pabrik semen sebagai bahan campuran untuk pembuatan batu bata.

PT. Semen Padang sebagai produsen semen dalam produksinya memerlukan kapur sebagai

merupakan salah satu bahan baku utama pada proses pembuatan semen selain tanah liat (Clay), yang merupakan sumber Kalsium Oksida $(\mathrm{CaO})$. campuran pembuatan semen. Dalam pengembangan usahanya (Indarung VI), karena keterbatasan cadangan batu gamping sebagai pasokan bahan baku pembuatan semen di area 206 ha (Bukit Karang Putih) menyebabkan relokasi ke area 412,3 ha (Bukit Tajarang). Pengoperasian penambangan ini berdampak terjadinya erosi permukaan pada saat terjadinya hujan dan hasil erosi tersebut mengalirkan ke sungai Batang Arau yang selanjutnya dapat menyebabkan sedimentasi didaerah hilir sungai. Luas areal penambangan yang direncanakan $4.120 .300 \mathrm{~m}^{2}$, jika dilakukan penambangan akan mengakibatkan laju erosi sebesar 454.584 ton/ha/tahun dan berdampak terjadinya pengendapan pada sungai Batang Arau dengan laju sedimentasi 619.853 ton/ha/tahun [4]. Laju sedimentasi yang besar tersebut dapat dimanfaatkan sebagai bahan campuran pembuatan batu bata karena matarial sedimentasi mengandung kapur dan lempung dengan gradasi yang sangat halus, sehingga diharapkan dapat meningkatkan kualitas batu bata dan mengurangi dampak sedimentasi sungai Batang Arau.

\section{Tinjauan Pustaka}

\section{Sedimentasi}

Sedimentasi adalah proses pengendapan material yang terangkut oleh aliran dari bagian hulu akibat dari erosi. Sedimen dapat berada di berbagai lokasi dalam aliran, tergantung pada keseimbangan antara kecepatan ke atas pada partikel (gaya tarik dan gaya angkat) dan kecepatan pengendapan partikel [5].

Sebagian dari sedimen akan masuk ke dalam sungai kemudian terbawa ke luar daerah tampungan seperti Daerah Aliran Sungai (DAS) sedangkan sebagian lagi akan mengendap pada bagian bawah lereng di sepanjang lintasan aliran permukaan [6].

Besarnya hasil sedimen sangat tergantung pada besar dari total erosi di suatu DAS dan keluarnya transpor partikel-partikel tanah yang tererosi dari DAS. Permukaan tanah yang tererosi di daerah tangkapan air tidak semuanya akan hanyut terbawa dan mengendap di tempat lain. Karena itu, biasanya besarnya hasil sedimen bervariasi mengikuti karakteristik fisik DAS.

\section{Batu Kapur (Gamping/Limestone)}

Batu kapur (limestone) adalah sebuah batuan sedimen dengan rumus kimia $\mathrm{CaCO}_{3}$ terdiri dari mineral Calcite (Calsium Carbonate). Batu Kapur 


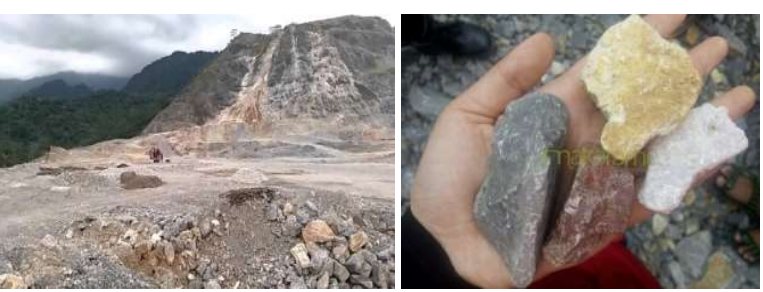

Gambar 1. Batu gamping

Penambangan terhadap endapan batu kapur dapat dilaksanakan dengan quarrying methods. Sebagian besar batu kapur mempunyai over burden yang tipis terdiri dari clay, pasir dan gravel. Yang menghendaki pengupasan over burden misalnya dengan hand shovel, scrapers, power shovels, hydraulicking. Bila over burden tersebut keras dengan pemboran dan peledakan. Bila over burden tebal maka penambangan secara underground mining.

\section{Material Penyusun Batu bata}

Bahan dasar pembentuk batu bata tergantung kepada jenis batu bata dan cara pembuatan. Jenis batu bata yang dibakar dan dijemur bahan yang dipakai adalah lempung. Lempung merupakan koloid dengan ukuran sangat kecil (kurang dari 1 mikron). Masing-masing koloid terlihat seperti lempengan-lempengan kecil yang terdiri dari lembaran-lembaran kristal yang memiliki struktur atom yang berulang. Lembaran-lembaran kristal tersebut adalah tetrahedron/silica sheet, dan octahedron/alumina sheet.

Sebagai bahan dalam proses reaksi pengikatan material untuk pembuatan batu bata digunakan air. Pemberian air pada kadar tertentu ini bertujuan agar batu bata mudah dicetak. Dalam pembuatan batu bata lempung, penambahan kadar air ditandai dengan tidak adanya penempelan lempung pada lapak tangan. Disamping itu perlu adanya pemeriksaan visual terhadap air yang digunakan seperti tidak berminyak, tidak mengandung sampah dan kotoran.

Batu bata lempung adalah batu bata yang terbuat dari lempung dengan atau tanpa campuran bahan lain melalui suatu proses pembakaran atau pengeringan. Batu bata lempung dibakar dengan temperatur tinggi hingga tidak hancur bila direndam dalam air dan mempunyai luas penampang lubang kurang dari $15 \%$ dari luas potongan datarnya. Batu bata lempung yang diproduksi melalui proses pembakaran lebih dikenal dengan nama bata merah.

Sifat teknis batu bata [7], antara lain:

1) Penyerapan (absorbtion) Batu Bata
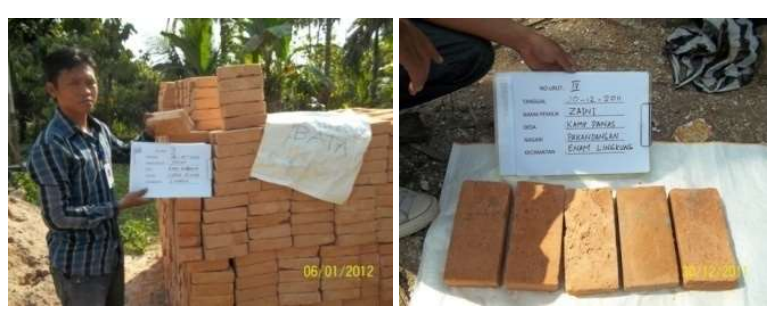

Gambar 2. Batu bata lempung

\section{Persyaratan Mutu Batu Bata}

Mutu suatu batu bata mengikuti persyaratan yang telah ditetapkan untuk mengetahui tingkat mutunya, adapun komponen-komponen mutu bata adalah:

\section{a. Sifat Fisis Batu Bata}

Sifat fisis batu bata adalah sifat yang ada pada batu bata tanpa adanya pemberian beban atau perlakuan apapun. Sifat fisis batu bata [8] antara lain:

1) Densitas atau Kerapatan Batu Bata Densitas adalah massa atau berat sampel yang terdapat dalam satu satuan volume. Densitas yang disyaratkan untuk digunakan adalah 1,60 $\mathrm{gr} / \mathrm{cm}^{3}-2,00 \mathrm{gr} / \mathrm{cm}^{3}$.

2) Persamaan yang digunakan dalam menghitung densitas atau kerapatan batu bata adalah:

$$
D=\frac{\text { Berat kering }}{\text { Volume }}
$$

3) Warna Batu Bata

Warna batu bata tergantung pada warna bahan dasar tanah, jenis campuran bahan tambahan jika ada dan proses berlangsungnya pembakaran. Standar warna batu bata adalah orange kecoklatan.

4) Dimensi atau Ukuran Batu Bata

Dimensi batu bata yang disyaratkan adalah batu bata harus memiliki ukuran panjang maksimal 16 in $(40 \mathrm{~cm})$, lebar berkisar antara 3 in -12 in $(7,50 \mathrm{~cm}-30,0 \mathrm{~cm})$ dan tebal berkisar antara 2 in -8 in $(5 \mathrm{~cm}-20 \mathrm{~cm})$.

5) Tekstur dan Bentuk Batu Bata

Bentuk batu bata berupa balok dengan ukuran panjang, lebar, tebal yang telah ditetapkan. Permukaan batu bata relatif datar dan kesat tapi tak jarang berukuran tidak beraturan.

\section{b. Sifat Mekanis Batu Bata}

Sifat mekanis batu bata adalah sifat yang ada pada batu bata jika dibebani atau dipengaruhi dengan perlakuan tertentu.

Penyerapan (absorbtion) adalah kemampuan maksimum batu bata untuk menyimpan atau menyerap air atau lebih 
dikenal dengan batu bata yang jenuh air. Pada penerapannya air adukan akan terserap oleh batu bata, air adukan ini berfungsi dalam proses pengerasan semen berkurang dan kekuatan mortar akan turun. Standar penyerapan (absorbtion) batu bata yang disyaratkan oleh ASTM C 67-03 adalah masing-masing maksimum $13 \%$ dan $17 \%$. Menurut SNI Penyerapan air maksimum dari batu bata merah pejal untuk pasangan dinding yang diizinkan adalah sebesar $20 \%$. Persamaan yang digunakan dalam menghitung penyerapan (absorbtion) batu bata adalah:

$\%$ penyerapan $=\frac{100(W s-W d)}{W d}(\%)$

dimana:

$W d=$ berat kering sampel $(\mathrm{N})$

$W S$ = berat jenuh sampel setelah direndam dalam air dingin $(\mathrm{N})$

2) Kuat Tekan Pasangan Batu Bata (Compressive Strength of Brick Prism)

Adalah kemampuan maksimum dari pekerjaan pasangan batu bata dengan mortar. Kuat tekan dinding pasangan batu bata lebih banyak dipengaruhi oleh kekuatan mortarnya, dan dibatasi oleh kekuatan batu bata. Sehingga ada kalanya penambahan kekuatan mortar tidak lagi Testing Machine (UTM).

\section{Pembuatan Sampel Batu Bata}

Pembuatan sampel atau benda uji batu bata campuran bahan sedimentasi dengan ukuran (20x10x5) $\mathrm{cm}$ sebanyak 50 buah dan untuk batu bata normal 50 buah. Adapun komposisi campuran pembuatan batu bata dengan bahan sedimentasi seperti tabel berikut:

Tabel 1. Komposisi sampel batu bata dicampur dengan bahan sedimentasi

\begin{tabular}{|c|c|c|c|}
\hline Sampel & $\begin{array}{c}\text { Banyak } \\
\text { Sampel }\end{array}$ & $\begin{array}{c}\text { Tanah } \\
\text { lempung } \\
(\%)\end{array}$ & $\begin{array}{c}\text { Bahan } \\
\text { sedimentasi } \\
(\%)\end{array}$ \\
\hline A & 5 & 50 & 50 \\
\hline B & 5 & 55 & 45 \\
\hline C & 5 & 60 & 40 \\
\hline D & 5 & 65 & 35 \\
\hline E & 5 & 70 & 30 \\
\hline F & 5 & 75 & 25 \\
\hline G & 5 & 80 & 20 \\
\hline H & 5 & 85 & 15 \\
\hline I & 5 & 90 & 10 \\
\hline J & 5 & 95 & 5 \\
\hline
\end{tabular}

memberikan perubahan yang signifikan terhadap kekuatan tekan dinding pasangan batu bata. Standar prosedur percobaan kuat tekan pasangan batu bata yang disyaratkan oleh SNI 15-2094-2000, dengan persamaan:

$\sigma=\frac{P}{A}$

Dimana:

$\mathrm{P}=$ Bebanyang diberikan $(\mathrm{N})$

$\mathrm{A}=$ Luas penampang $\left(\mathrm{cm}^{2}\right)$

\section{METODE}

Penelitian ini dilakukan di pabrik batu bata Jalan Tapakih Kecamatan Lubuk Alung Kabupaten Padang Pariaman dengan membuat benda uji berupa batu bata dengan campuran hasil sedimentasi. Selanjutnya dilakukan uji mutu di Laboratorium Bahan Jurusan Teknik Sipil Fakultas Teknik Universitas Negeri Padang.

\section{Alat dan Bahan}

Bahan yang dipergunakan untuk pembuatan batu bata antara lain tanah lempung, hasil sedimentasi batu kapur dan air. Sedangkan peralatan yang digunakan adalah pabrik pembuatan batu bata, timbangan, ember, tempat adukan, oven pengering dan Universal

Pembuatan batu bata, mulai dari pengolahan bahan, pencetakan dan pembakaran sesuai dengan metode yang ada/lazim pada pembuatan pabrik batu bata yang ada (tidak merekayasa metode pembuatan), seperti pada gambar 3 .

\section{Perawatan dan pengujian benda uji}

Perawatan benda uji (Curing time) dilakukan setelah pencetakan dan pembakaran batu bata yang lebih dan kurang selama 6 hari x 24 jam dan mendapatkan hasil yang maksimal dilakukan pembakaran pada suhu yang tinggi atau telah disesuaikan. Selanjutnya dilakukan pengujian batu bata seperti sifat tampak, ukuran dan toleransi, kuat tekan dan penyerapan air batu bata. 


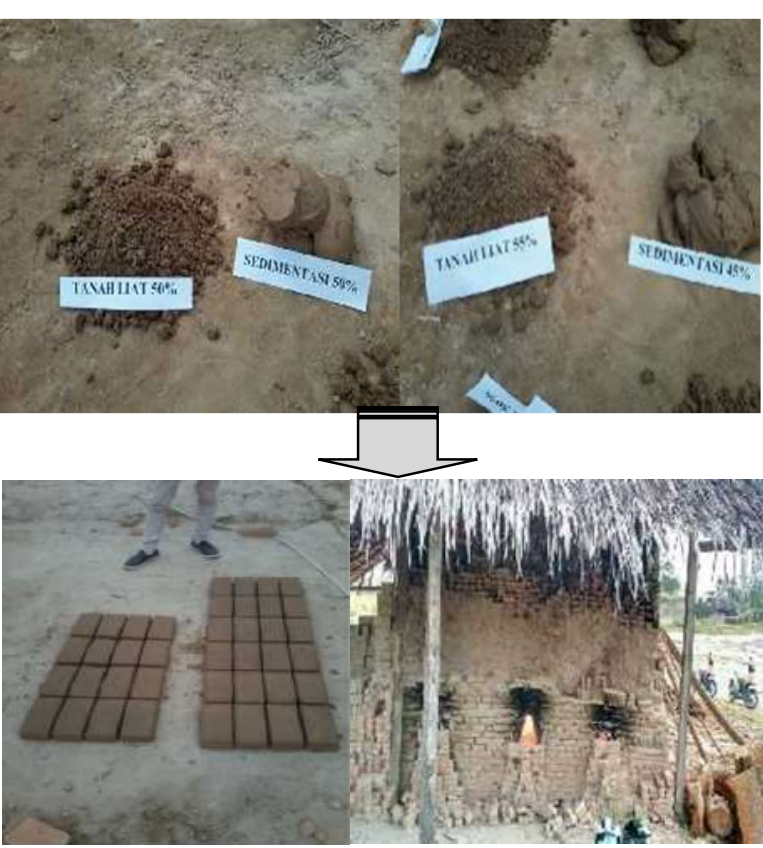

Gambar 3. Proses pembuatan benda uji

\section{Hasil dan Pembahasan}

\section{Hasil Pengujian}

a. Sifat Fisis Batu Bata

1) Densitas atau Kerapatan Batu Bata

Hasil pengujian dansitas batu bata normal dan batu bata dengan campuran bahan sedimentasi adalah:

Tabel 2. Densitas batu bata

\begin{tabular}{|c|c|c|}
\hline \multirow{2}{*}{$\begin{array}{c}\text { Benda } \\
\text { Uji }\end{array}$} & \multicolumn{2}{|c|}{ Densitas $\left(\mathrm{gr} / \mathrm{cm}^{3}\right)$} \\
\cline { 2 - 3 } & $\begin{array}{c}\text { Batu bata } \\
\text { Campuran }\end{array}$ & $\begin{array}{c}\text { Batu bata } \\
\text { normal }\end{array}$ \\
\hline A & 1,27 & 1,35 \\
\hline B & 1,30 & 1,20 \\
\hline C & 1,52 & 1,34 \\
\hline D & 1,46 & 1,38 \\
\hline E & 1,43 & 1,44 \\
\hline F & 1,40 & 1,31 \\
\hline G & 1,52 & 1,29 \\
\hline H & 1,35 & 1,33 \\
\hline I & 1,34 & 1,38 \\
\hline J & 1,51 & 1,18 \\
\hline
\end{tabular}

2) Warna Batu Bata

Hasil pengamatan warna, menunjukkan warna batu bata adalah merah keputihan, hal ini disebabkan karena materiak sedimen dari erosi penambangan banyak mengandung kapur. Warna ini berbeda dengan batu bata tanah lempung dengan warna dominan coklat kemerahan karena banyak mengandung lempung dan lanau.

3) Dimensi atau Ukuran Batu Bata

Ukuran batu bata harus memenuhi persyaratan standar sesuai SNI 15-2094-2000 dipakai modul 5a adalah panjang $190 \mathrm{~mm}$, lebar $92 \mathrm{~mm}$ dan tebal $65 \mathrm{~mm}$. Dari hasil pengujian dapat dilihat perbandingan antara panjang dengan lebar dan antara lebar dengan tebalnya seperti pada tabel berikut ini:

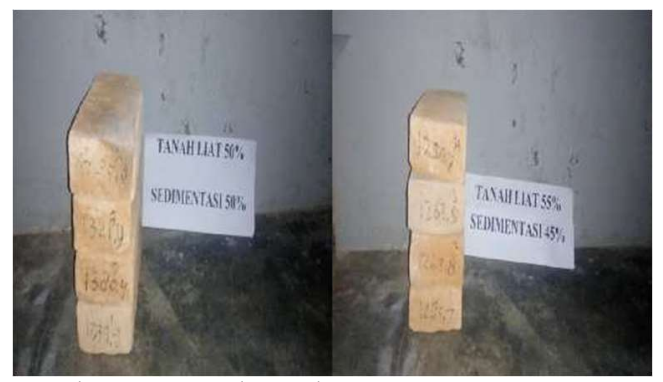

Gambar 4. Batu bata dengan campuran bahan sedimentasi

TABEL 3. Hasil pengujian ukuran batu bata

\begin{tabular}{|c|c|c|c|c|c|c|c|}
\hline \multirow{2}{*}{\multicolumn{2}{|c|}{$\begin{array}{c}\text { Benda } \\
\text { Uji }\end{array}$}} & \multicolumn{3}{|c|}{ Bata sedimentasi } & \multicolumn{3}{|c|}{ Bata normal } \\
\hline & & \multirow{2}{*}{$\begin{array}{c}\begin{array}{c}\mathrm{P} \\
(\mathrm{mm})\end{array} \\
193\end{array}$} & \multirow{2}{*}{$\begin{array}{c}\begin{array}{c}\mathrm{L} \\
(\mathrm{mm})\end{array} \\
96\end{array}$} & \multirow{2}{*}{$\begin{array}{c}\begin{array}{c}\mathrm{T} \\
(\mathrm{mm})\end{array} \\
195\end{array}$} & \multirow{2}{*}{$\begin{array}{c}\begin{array}{c}\mathrm{P} \\
(\mathrm{mm})\end{array} \\
99\end{array}$} & \multirow{2}{*}{$\begin{array}{c}\begin{array}{c}\mathrm{L} \\
(\mathrm{mm})\end{array} \\
49\end{array}$} & \multirow{2}{*}{$\begin{array}{c}\begin{array}{c}\mathrm{T} \\
(\mathrm{mm})\end{array} \\
50\end{array}$} \\
\hline & 1 & & & & & & \\
\hline & 2 & 195 & 98 & 196 & 99 & 48 & 50 \\
\hline A & 3 & 196 & 95 & 189 & 99 & 51 & 49 \\
\hline & 4 & 191 & 99 & 192 & 100 & 51 & 50 \\
\hline \multirow{4}{*}{$\mathrm{B}$} & 1 & 191 & 99 & 190 & 98 & 50 & 50 \\
\hline & 2 & 187 & 97 & 191 & 99 & 49 & 49 \\
\hline & 3 & 191 & 99 & 191 & 98 & 55 & 49 \\
\hline & 4 & 194 & 95 & 189 & 97 & 51 & 50 \\
\hline \multirow{4}{*}{ C } & 1 & 190 & 94 & 192 & 97 & 50 & 48 \\
\hline & 2 & 190 & 96 & 189 & 96 & 50 & 48 \\
\hline & 3 & 189 & 97 & 189 & 97 & 54 & 49 \\
\hline & 4 & 191 & 99 & 195 & 98 & 50 & 51 \\
\hline \multirow{4}{*}{ D } & 1 & 190 & 94 & 190 & 97 & 46 & 49 \\
\hline & 2 & 193 & 94 & 189 & 99 & 53 & 51 \\
\hline & 3 & 190 & 97 & 189 & 97 & 50 & 49 \\
\hline & 4 & 191 & 100 & 194 & 96 & 50 & 50 \\
\hline \multirow{4}{*}{$\mathrm{E}$} & 1 & 190 & 95 & 196 & 97 & 52 & 50 \\
\hline & 2 & 185 & 95 & 189 & 99 & 51 & 46 \\
\hline & 3 & 196 & 96 & 192 & 97 & 50 & 52 \\
\hline & 4 & 190 & 95 & 190 & 96 & 50 & 49 \\
\hline \multirow{4}{*}{$\mathrm{F}$} & 1 & 192 & 97 & 195 & 98 & 52 & 48 \\
\hline & 2 & 192 & 95 & 189 & 95 & 51 & 50 \\
\hline & 3 & 188 & 99 & 192 & 99 & 50 & 51 \\
\hline & 4 & 190 & 98 & 192 & 100 & 50 & 52 \\
\hline \multirow{4}{*}{$\mathrm{G}$} & 1 & 193 & 96 & 195 & 96 & 52 & 47 \\
\hline & 2 & 192 & 100 & 185 & 101 & 50 & 49 \\
\hline & 3 & 192 & 95 & 190 & 96 & 53 & 49 \\
\hline & 4 & 189 & 94 & 192 & 97 & 51 & 47 \\
\hline \multirow{4}{*}{$\mathrm{H}$} & 1 & 193 & 96 & 188 & 97 & 53 & 46 \\
\hline & 2 & 194 & 95 & 190 & 90 & 52 & 47 \\
\hline & 3 & 194 & 94 & 193 & 99 & 50 & 49 \\
\hline & 4 & 194 & 100 & 188 & 99 & 53 & 48 \\
\hline \multirow{4}{*}{ I } & 1 & 189 & 98 & 192 & 99 & 50 & 51 \\
\hline & 2 & 195 & 97 & 189 & 98 & 49 & 49 \\
\hline & 3 & 192 & 95 & 186 & 97 & 52 & 47 \\
\hline & 4 & 190 & 97 & 193 & 97 & 49 & 48 \\
\hline \multirow{4}{*}{$\mathrm{J}$} & 1 & 191 & 97 & 191 & 100 & 49 & 47 \\
\hline & 2 & 195 & 95 & 195 & 96 & 51 & 51 \\
\hline & 3 & 190 & 98 & 192 & 98 & 53 & 51 \\
\hline & 4 & 191 & 96 & 194 & 102 & 52 & 49 \\
\hline
\end{tabular}


4) Tekstur dan bentuk batu bata

Batu bata harus mempunyai rusuk-rusuk yang tajam dan siku, bidang sisinya harus datar, tidak menunjukkan retak-retak pada permukaan bata dan perubahan bentuk yang tidak berlebihan, tidak mudah patah dan hancur, dan berbunyi bila dipukul. Tabel 4 . Berikut menunjukkan hasil pengujian sifat tampak dengan pengamatan visual.

Tabel 4. Hasil Pengujian tekstur dan bentuk batu

\begin{tabular}{|c|c|c|c|c|c|c|c|}
\hline \multirow{2}{*}{\multicolumn{2}{|c|}{$\begin{array}{c}\text { Benda } \\
\text { Uji }\end{array}$}} & \multicolumn{3}{|c|}{$\begin{array}{c}\text { Batu bata dengan } \\
\text { campuran bahan } \\
\text { Sedimentasi }\end{array}$} & \multicolumn{3}{|c|}{$\begin{array}{c}\text { Batu bata dengan } \\
\text { bahan } \\
\text { lempung }\end{array}$} \\
\hline & & \multicolumn{2}{|c|}{$\begin{array}{c}\text { Bentuk } \\
\text { Permukaan }\end{array}$} & \multirow{2}{*}{$\frac{\text { Kesikuan }}{\text { TS }}$} & \multicolumn{2}{|c|}{$\begin{array}{c}\text { Bentuk } \\
\text { permukaan }\end{array}$} & \multirow{2}{*}{$\begin{array}{c}\text { Kesikuan } \\
\text { TS }\end{array}$} \\
\hline & $\mathrm{a}$ & $\mathrm{R}$ & TRk & & TR & TRk & \\
\hline & $\mathrm{b}$ & $\mathrm{R}$ & TRk & TS & TR & TRk & TS \\
\hline & $\mathrm{c}$ & TR & TRk & $\mathrm{TS}$ & TR & TRk & TS \\
\hline & $\mathrm{d}$ & TR & $\mathrm{Rk}$ & TS & $\mathrm{R}$ & TRk & TS \\
\hline \multirow{4}{*}{ B } & $\mathrm{a}$ & TR & TRk & TS & TR & TRk & TS \\
\hline & $\mathrm{b}$ & TR & $\mathrm{Rk}$ & TS & $\mathrm{R}$ & TRk & TS \\
\hline & $\mathrm{c}$ & TR & TRk & TS & TR & TRk & TS \\
\hline & $\mathrm{d}$ & $\mathrm{R}$ & $\mathrm{Rk}$ & TS & TR & TRk & TS \\
\hline \multirow{4}{*}{$\mathrm{C}$} & $a$ & $\mathrm{R}$ & TRk & TS & $\mathrm{R}$ & TRk & TS \\
\hline & $\mathrm{b}$ & TR & TRk & TS & TR & TRk & TS \\
\hline & $\mathrm{c}$ & TR & TRk & TS & TR & $\mathrm{Rk}$ & TS \\
\hline & $\mathrm{d}$ & TR & $\mathrm{Rk}$ & TS & TR & $\mathrm{Rk}$ & TS \\
\hline \multirow{4}{*}{ D } & $\mathrm{a}$ & TR & TRk & TS & TR & TRk & TS \\
\hline & $b$ & $\mathrm{R}$ & $\mathrm{Rk}$ & TS & $\mathrm{R}$ & $\mathrm{Rk}$ & TS \\
\hline & $\mathrm{c}$ & TR & TRk & TS & TR & TRk & TS \\
\hline & $\mathrm{d}$ & TR & TRk & TS & TR & TRk & TS \\
\hline \multirow{4}{*}{$\mathrm{E}$} & $a$ & TR & $\mathrm{Rk}$ & TS & $\mathrm{R}$ & TRk & $\mathrm{TS}$ \\
\hline & $\mathrm{b}$ & TR & TRk & TS & $\mathrm{R}$ & TRk & TS \\
\hline & $\mathrm{c}$ & TR & $\mathrm{Rk}$ & $\mathrm{TS}$ & $\mathrm{R}$ & TRk & $\mathrm{TS}$ \\
\hline & $\mathrm{d}$ & TR & TRk & TS & TR & TRk & TS \\
\hline \multirow{4}{*}{$\mathrm{F}$} & $\mathrm{a}$ & TR & TRk & TS & TR & $\mathrm{Rk}$ & $\mathrm{TS}$ \\
\hline & $\mathrm{b}$ & TR & TRk & $\mathrm{TS}$ & TR & TRk & $\mathrm{TS}$ \\
\hline & c & $\mathrm{R}$ & TRk & TS & $\mathrm{R}$ & $\mathrm{Rk}$ & TS \\
\hline & $\mathrm{d}$ & TR & $\mathrm{Rk}$ & TS & $\mathrm{R}$ & TRk & TS \\
\hline \multirow{4}{*}{ G } & $\mathrm{a}$ & TR & TRk & TS & TR & $\mathrm{Rk}$ & TS \\
\hline & $\mathrm{b}$ & TR & TRk & TS & TR & $\mathrm{Rk}$ & TS \\
\hline & $\mathrm{c}$ & TR & TRk & TS & $\mathrm{R}$ & TRk & TS \\
\hline & $\mathrm{d}$ & $\mathrm{R}$ & TRk & TS & TR & TRk & TS \\
\hline \multirow{4}{*}{$\mathrm{H}$} & a & TR & TRk & TS & $\mathrm{R}$ & TRk & TS \\
\hline & $\mathrm{b}$ & TR & TRk & TS & $\mathrm{R}$ & TRk & TS \\
\hline & $\mathrm{c}$ & TR & $\mathrm{Rk}$ & TS & $\mathrm{R}$ & TRk & TS \\
\hline & $\mathrm{d}$ & TR & TRk & TS & TR & TRk & TS \\
\hline \multirow{4}{*}{ I } & $\mathrm{a}$ & TR & $\mathrm{Rk}$ & TS & $\mathrm{R}$ & $\mathrm{Rk}$ & TS \\
\hline & $\mathrm{b}$ & TR & TRk & TS & TR & TRk & TS \\
\hline & $\mathrm{c}$ & TR & TRk & TS & $\mathrm{R}$ & TRk & TS \\
\hline & $\mathrm{d}$ & TR & TRk & TS & TR & TRk & TS \\
\hline \multirow{4}{*}{$\mathrm{J}$} & $\mathrm{a}$ & TR & TRk & TS & $\mathrm{R}$ & TRk & TS \\
\hline & $\mathrm{b}$ & TR & TRk & TS & $\mathrm{R}$ & $\mathrm{Rk}$ & TS \\
\hline & $\mathrm{c}$ & TR & TRk & TS & $\mathrm{R}$ & Rk & TS \\
\hline & $\mathrm{d}$ & $\mathrm{R}$ & TRk & TS & TR & TRk & TS \\
\hline
\end{tabular}

Ket: $R$ (Rata), TR (tidak rata), TRk (tidak retak), Rk (retak), S (siku), TS (tidak siku).

\section{b. Sifat Mekanis Batu Bata}

1) Kuat Tekan Batu Bata
Mutu kuat tekan batu bata sesuai dengan yang disyaratkan pada SNI diambil persyaratan minimum kuat tekan batu bata, yaitu kelas 50 dengan kuat tekan 50 $\mathrm{kg} / \mathrm{cm}^{2}$. Sebelum melakukan pengujian kuat tekan, batu bata dipotong menjadi 2 bagian, kemudian batu bata diberi mortar untuk di uji kuat tekan.

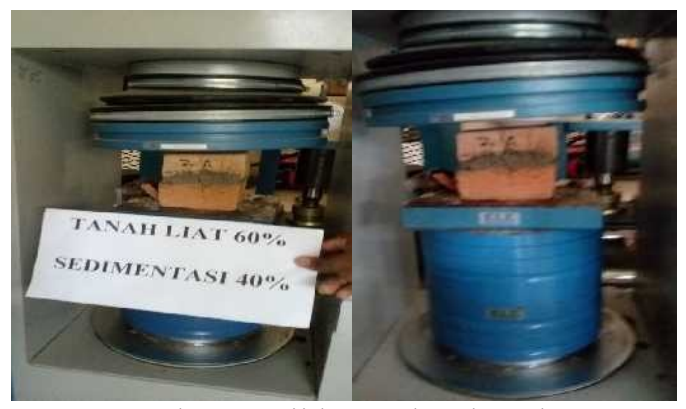

Gambar 5. Uji kuat tekan batu bata

Hasil pengujian kuat tekan dari 30 sampel batu bata campuran bahan sedimentasi dan 30 sampel batu bata biasa tersaji pada tabel berikut:

Tabel 5. Hasil kuat tekan batu bata

\begin{tabular}{|c|c|c|}
\hline $\begin{array}{c}\text { Benda } \\
\text { uji }\end{array}$ & $\begin{array}{c}\text { Kuat tekan } \\
\text { rata-rata bata } \\
\text { campuran } \\
\text { sedimentasi } \\
\left(\mathrm{kg} / \mathrm{cm}^{2}\right)\end{array}$ & $\begin{array}{c}\text { Kuat tekan } \\
\text { rata-rata bata } \\
\text { normal } \\
\left(\mathrm{kg} / \mathrm{cm}^{2}\right)\end{array}$ \\
\hline A & 33,1 & 12,08 \\
\hline B & 36,06 & 13,08 \\
\hline C & 36,10 & 13,08 \\
\hline D & 36,14 & 11,78 \\
\hline E & 42,14 & 13,64 \\
\hline F & 35,22 & 14,33 \\
\hline G & 31,23 & 12,45 \\
\hline H & 30,44 & 11,46 \\
\hline I & 25,26 & 9,82 \\
\hline J & 19,93 & 10,98 \\
\hline
\end{tabular}

2) Penyerapan (absorbtion) Batu Bata

Hasil pengujian penyerapan air batu bata dengan campuran bahan sedimentasi dan batu bata lempung mengacu kepada standar penyerapan (absorbtion) batu bata yang disyaratkan oleh ASTM C 67-03 adalah masing-masing maksimum $13 \%$ dan $17 \%$. Menurut SNI Penyerapan air maksimum dari batu bata merah pejal untuk pasangan dinding yang diizinkan adalah sebesar $20 \%$. 
Tabel 6. Hasil Pengujian Penyerapan Air Batu Bata

\begin{tabular}{|c|c|c|c|c|c|c|}
\hline \multirow{3}{*}{$\begin{array}{l}\text { Benda } \\
\text { uji }\end{array}$} & \multicolumn{3}{|c|}{$\begin{array}{l}\text { Batu bata dengan campuran bahan } \\
\text { sedimentasi }\end{array}$} & \multicolumn{3}{|c|}{ Batu bata dengan bahan lempung } \\
\hline & \multicolumn{2}{|c|}{ Berat batu bata (gr) } & \multirow{2}{*}{$\begin{array}{c}\text { Penyerapan Air } \\
(\%)\end{array}$} & \multicolumn{2}{|c|}{ Berat batu bata (gr) } & \multirow{2}{*}{$\begin{array}{l}\text { Penyerapan Air } \\
(\%)\end{array}$} \\
\hline & Basah & Kering & & Basah & Kering & \\
\hline A & 1480,80 & 1271,80 & 16,43 & 1512,50 & 1285,10 & 17,70 \\
\hline $\mathrm{B}$ & 1480,90 & 1298,70 & 14,03 & 1456,10 & 1151,30 & 26,47 \\
\hline $\mathrm{C}$ & 1507,10 & 1324,20 & 13,81 & 1474,40 & 1220,00 & 20,85 \\
\hline $\mathrm{D}$ & 1539,60 & 1358,90 & 13,30 & 1480,10 & 1223,50 & 20,97 \\
\hline $\mathrm{E}$ & 1500,30 & 1324,00 & 13,32 & 1618,20 & 1365,80 & 18,48 \\
\hline $\mathrm{F}$ & 1505,50 & 1300,30 & 15,78 & 1543,80 & 1250,70 & 23,43 \\
\hline $\mathrm{G}$ & 1496,00 & 1314,90 & 13,77 & 1479,70 & 1233,10 & 20,00 \\
\hline $\mathrm{H}$ & 1489,70 & 1312,30 & 13,52 & 1473,70 & 1237,20 & 19,12 \\
\hline $\mathrm{I}$ & 1504,90 & 1319,10 & 14,09 & 1498,60 & 1283,80 & 16,73 \\
\hline $\mathrm{J}$ & 1498,40 & 1320,10 & 13,51 & 1474,30 & 1152,00 & 27,98 \\
\hline
\end{tabular}

\section{Pembahasan}

Hasil pengujian sifat tampak rata-rata untuk batu bata campuran sedimentasi memiliki rata $20 \%$ dan tidak rata $80 \%$, keretakan didapat retak $25 \%$ dan tidak retak $75 \%$. Sedangkan rata-rata untuk batu bata biasa rata $45 \%$ dan tidak rata $55 \%$, retak $25 \%$ dan tidak retak $75 \%$. Untuk kesikuan pada kedua jenis batu bata tidak memiliki sudut yang siku-siku. Sedangkan nilai penyimpangan yang lebih besar terdapat pada batu bata campuran sedimentasi dengan ukuran salah satu penyimpangan ukuran tinggi batu bata yaitu $19 \mathrm{~mm}$ dan hal yang sama juga terdapat pada batu bata biasa, dengan persyaratan ukuran sesuai dengan modul 5a pada SNI 15-2094-2000. Kondisi ini disebabkan karena waktu pembakaran

yang kurang, pasta tanah yang terlalu encer dan perlakuan pasca pencetakan sebelum pembakaran yang kurang baik.

Perbandingan nilai rata-rata penyerapan air dan kuat tekan dari batu bata berbahan lempung dan batu bata dengan campuran bahan sedimentasi hasil erosi penambangan batu kapur (limestone) tanpa merubah metode pembuatan batu bata tradisional yang ada di pabrik batu bata Jalan Tapakih Kecamatan Lubuk Alung Kabupaten Padang Pariaman, tersaji pada gambar 6.
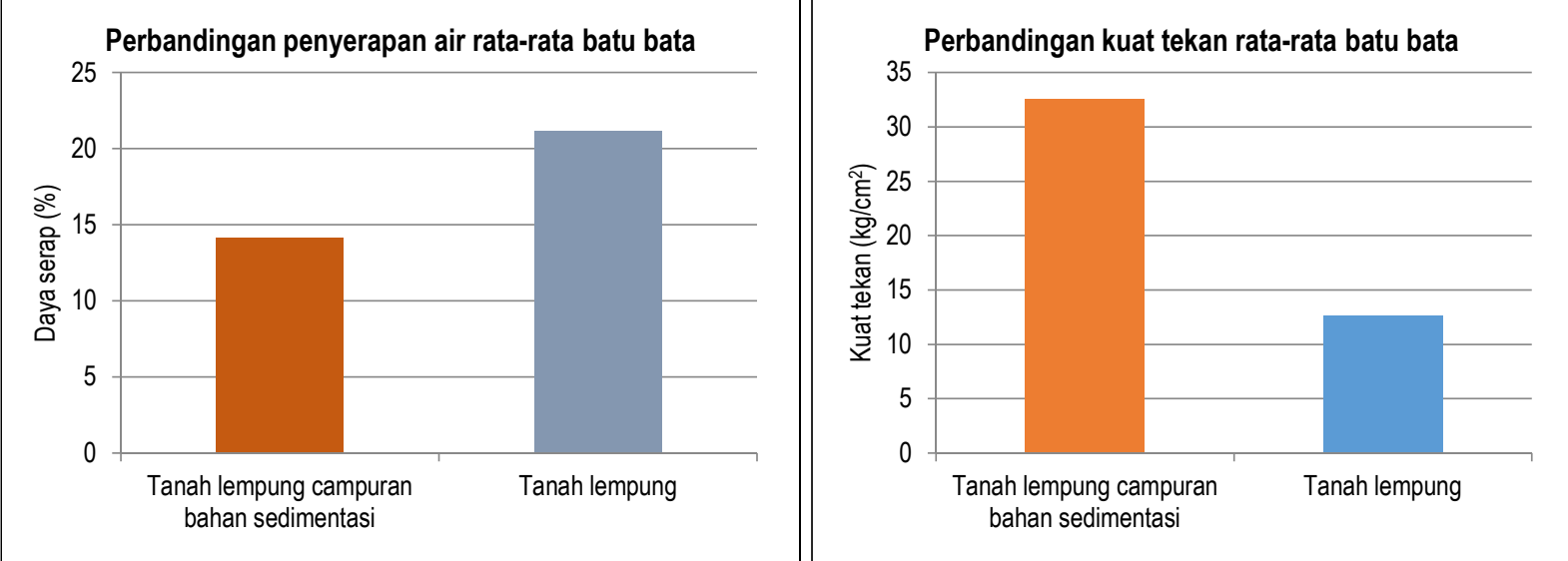

Gambar 6. Perbandingan penyerapan air dan kuat tekan batu bata campuran bahan sedimentasi dengan batu bata tanah lempung

Berdasarkan grafik di atas, penyerapan air batu bata campuran bahan sedimentasi lebih kecil $(14,16 \%)$ dibandingkan batu bata tanah lempung/tanpa campuran $(21,17)$. Hal ini menunjukan bahwa daya serap batu bata campuran bahan sedimentasi memenuhi persyaratan SNI 15-2094-000 yang mensyaratkan daya serap air batu bata maksimum
20\%. Sementara nilai perbandingan kuat tekan rata-rata batu bata campuran bahan sedimentasi lebih besar $\left(32,56 \mathrm{~kg} / \mathrm{cm}^{2}\right)$ dibandingkan batu bata tanah lempung yang hanya sebesar $12,58 \mathrm{~kg} / \mathrm{cm}^{2}$. Nilai kuat tekan batu bata dengan campuran bahan sedimentasi memenuhi persyaratan kuat tekan minimum membangun rumah aman gempa ( $\geq 30$ 
Mengacu kepada hasil yang diperoleh maka batu bata dengan campuran bahan sedimentasi batu gamping (limestone) lebih baik mutunya dibandingkan batu bata tanah lempung saja. Untuk melihat komposisi campuran bahan sedimentasi yang terbaik berikut ini disajikan kurva perbandingan antara kuat tekan, daya serap air dan densitas batu bata dari 10 komposisi yang dibuat.

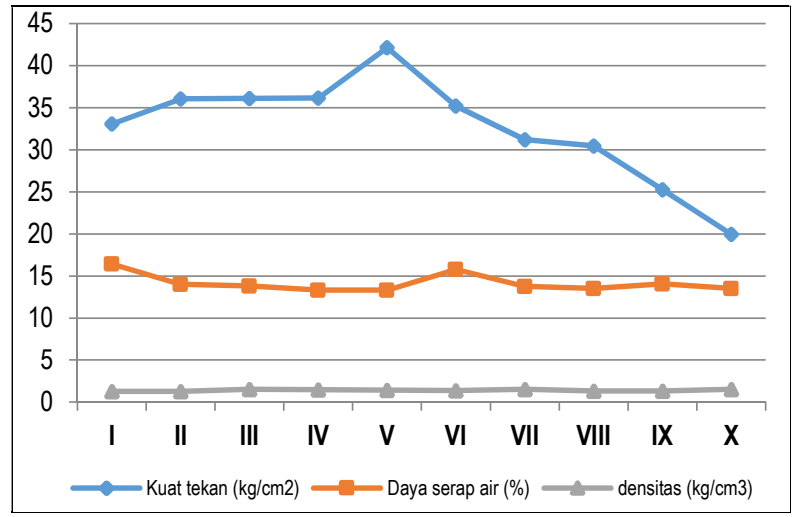

Gambar 7. Perbandingan kuat tekan, daya serap dan densitas batu bata campuran bahan sedimentasi

Gambar 7. menunjukan bahwa komposisi E (70\% tanah lempung, 30\% bahan sedimentasi) adalah batu bata mutu tertinggi dengan kuat tekan tertinggi, daya serap air rendah dan densitas yang tinggi/padat (memenuhi kriteria persyaratan mutu batu bata).

\section{Kesimpulan}

Pengujian sifat tampak batu bata campuran sedimentasi dengan batu bata biasa, didapatkan hasil pengujian sifat tampak dan ukuran toleransi, tidak memenuhi persyaratan karena rata-rata tidak mencapai yang disyaratkan sesuai SNI 15-2094-2000.

Penyerapan air batu bata campuran hasil sedimentasi memenuhi persyaratan mutu $(14,16 \%)$, yaitu daya serap air batu bata maksimum $20 \%$.

Kuat tekan rata-rata batu bata campuran bahan sedimentasi sebesar $32,56 \mathrm{~kg} / \mathrm{cm}^{2}$, memenuhi persyaratan kuat tekan minimum membangun rumah aman gempa $\left(\geq 30 \mathrm{~kg} / \mathrm{cm}^{2}\right)$.

Batu bata dengan komposisi campuran $70 \%$ tanah lempung, $30 \%$ bahan sedimentasi, memberikan mutu bata tertinggi.

\section{DAfTar Pustaka}

[1] ASTM C 67-03, "Standard Test Methods for Sampling and Testing Brick and Structural Clay Tile”, USA., 2003.

[2] Totoh Andayono, "Karakteristik Batu Bata dan Mortar untuk Pasangan Dinding Pasca Sosialisasi Membangun Rumah yang Lebih Aman Terhadap Gempa Dipesisir Pantai Kota Padang", Proseding Seminar Nasional APTEKINDO ke 8 Medan ISBN 978-602-74864- 0-9. 2016

[3] Alas Consultant, "Amdal Indarung VI PT. Semen Padang", Laporan Amdal, 2014.

[4] Chay Asdak, "Hidrologi dan Pengelolaan Daerah Aliran Sungai", Gadjah Mada University Press, Yogyakarta, 2004.

[5] Eka J, Bambang. H dan Totoh Andayono, "Brick Characteristic in West Sumatera", Proceeding UNESCO-IPRED-PUC International Workshop, pp 110-120, 2011.

[6] Irwan Sukri Banuwa, "Erosi", Prenada Media Group, Jakarta, 2013.

[7] Moch. Tri Rochadi dan F.X. Gunarsa Irianta, "Kualitas batu bata merah dari pemanfaatan tanah bantaran sungai banjir kanal Timur", Jurnal Wahana Teknik Sipil Vol. 12, No. 1, hal. 42-50. Politeknik Negeri Semarang

[8] Oscar Fithrah Nur, “Analisa sifat fisis dan mekanis

\section{Biodata Penulis}

Totoh Andayono, lahir pada tanggal 27 Juli 1973. Sarjana Teknik diraih tahun 1998 dari UBH dan Magister Teknik tahun 2003 dari UGM. Sejak tahun 2005 sebagai dosen di Jurusan Teknik Sipil, FT-UNP.

Eka Juliafad, lahir di Padang 30 Juli 1980. Sarjana S1 dan S2 diselesaika di UGM. Tahun 2018 menyelesaikan S3 dari Tokyo University. Sebagai dosen Teknik Sipil FT-UNP sejak tahun 2009.

Rusydi Halim, lahir di Sarik Taba, 17 Januari 1994. Pendidikan Sarjana diselesaikan tahun 2105, di Jurusan Teknik Sipil, FT-UNP dan FT, ITP. Saat ini bekerja sebagai konsultan di perusahaan konstruksi. 
